The Free Internet Journal

for Organic Chemistry
Review

Arkivoc 2020, part iv, 1-11

\title{
Hypervalent iodine compounds: reagents of the future
}

\author{
Viktor V. Zhdankin \\ Department of Chemistry and Biochemistry, University of Minnesota Duluth, \\ Duluth, Minnesota 55 812, USA \\ Email: vzhdanki@d.umn.edu
}

Received 01-01-2020

Accepted $01-26-2020$

Published on line $01-31-2020$

\section{Abstract}

This short introductory review provides a brief summary of history and recent developments in the field of hypervalent iodine chemistry in connection with the 7th International Conference on Hypervalent lodine Chemistry (ICHIC-2021, Moscow, $27^{\text {th }}$ June to $1^{\text {st }}$ July, 2021). Hypervalent iodine reagents and catalysts are intensively used in modern organic chemistry as mild, environmentally safe, and economical alternative to heavy metal reagents. General features and applications of hypervalent iodine compounds are overviewed.

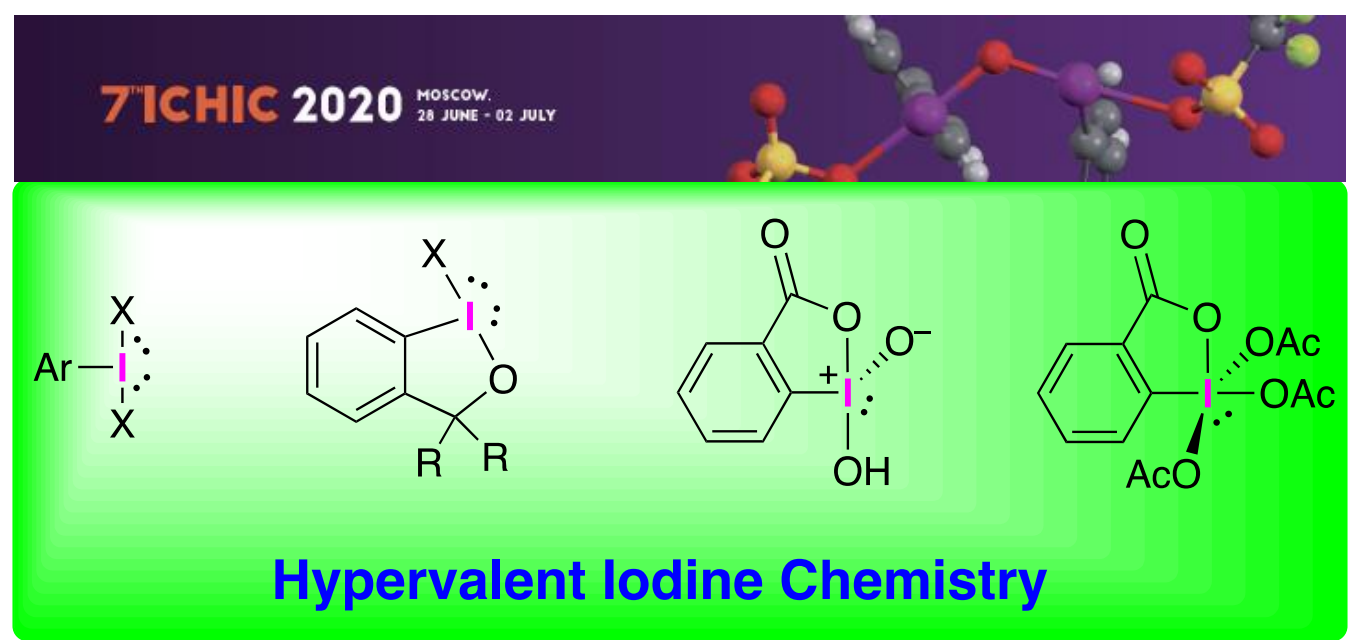

Keywords: lodine, hypervalent iodine, iodonium, oxidation 


\section{Table of Contents}

1. Introduction

2. Brief history of Organohypervalent lodine Chemistry

3. General Classification of Hypervalent lodine Compounds

4. Recent Developments and Future Perspectives

5. Conclusions

6. Acknowledgements

References

\section{Introduction}

lodine is an essential element closely linked to our daily life. ${ }^{1}$ In the human body, iodine is present in the thyroid gland in the form of thyroxine, a metabolism-regulating hormone. In natural organic compounds, iodine occurs exclusively in the monovalent state. However, it can form a myriad of polycoordinated compounds in different oxidation states. In modern literature, polyvalent compounds of iodine are commonly named as "hypervalent" iodine compounds, which reflects the special [3c-4e] hypervalent bonding present in these molecules. ${ }^{2-5}$ Structural features and reactivity pattern of hypervalent iodine compounds in many aspects are similar to the derivatives of heavy transition metals. Reactions of iodine compounds are commonly discussed in terms of oxidative addition, ligand exchange, reductive elimination, and ligand coupling, which are typical of the transition metal chemistry. In contrast to the heavy metals, iodine is an environmentally friendly and a relatively inexpensive element. Current average bulk price of iodine varies within the range of \$10-20 per $\mathrm{kg}$, which is orders of magnitude cheaper than platinum, palladium, or osmium. Organic compounds of polyvalent iodine have emerged as versatile, efficient and environmentally friendly synthetic reagents with numerous applications in academic and industrial research. ${ }^{6-9}$ Hypervalent iodine compounds are widely used as mild and selective oxidants and electrophilic group transfer reagents in organic synthesis. Diaryliodonium salts have found widespread industrial application as initiators of polymerization. ${ }^{9}$ This introductory review is published in connection with the 7th International Conference on Hypervalent lodine Chemistry (ICHIC-2021, Moscow, $27^{\text {th }}$ June to $1^{\text {st }}$ July 2021). A brief summary of general features and applications of hypervalent iodine compounds is provided and the history and recent developments in the field of hypervalent iodine chemistry are overviewed.

\section{Brief History of Organohypervalent lodine Chemistry}

The first polycoordinated organoiodine compound, (dichloroiodo)benzene, was reported by the German chemist C. Willgerodt in $1886 .{ }^{10}$ This was followed by the preparation of (diacetoxyiodo)benzene ${ }^{11}$ and iodosylbenzene $^{12}$ in 1892, 2-iodoxybenzoic acid (IBX) in 1893, ${ }^{13}$ and diaryliodonium salts reported by Hartmann and Meyer in $1894 .^{14}$ In 1914 Willgerodt published a comprehensive book describing almost 500 organic compounds of polyvalent iodine known at that time. ${ }^{15}$ Research activity in the area of polyvalent organoiodine compounds during the period between 1914 and 1970s was relatively low and represented mainly by valuable contributions from the laboratories of I. Masson, R. B. Sandin, F. M. Beringer, K. H. 
Pausacker, A. N. Nesmeyanov, and O. Neilands. Two significant reviews were published during this period: the reviews by Sandin ${ }^{16}$ and Banks ${ }^{17}$ published in Chemical Reviews in 1943 and 1966.

Since the end of 1970 s - beginning of 1980s the interest in polyvalent organoiodine compounds has experienced a renaissance. This resurgence of interest in polyvalent organic iodine has been initiated by the discovery of several new classes of polyvalent organoiodine compounds and, most notably, by the development of useful synthetic applications of some of these compounds, which are now regarded as valuable organic reagents known under general name of hypervalent iodine reagents. The foundation of modern hypervalent iodine chemistry was laid out in the 1980 s by the groundbreaking works of G. F. Koser, J. C. Martin, R. M. Moriarty, P. J. Stang, A. Varvoglis, and N. S. Zefirov.

Important contributions to the development of hypervalent iodine chemistry in the 1990s had been made by the research groups of A. Varvoglis, N. S. Zefirov, L. M. Yagupolskii, A. R. Katritzky, R. A. Moss, J. C. Martin, D. H. R. Barton, R. M. Moriarty, G. F. Koser, P. J. Stang, H.-J. Frohn, T. Umemoto, M. Yokoyama, Y. Kita, M. Ochiai, T. Okuyama, T. Kitamura, H. Togo, E. Dominguez, I. Tellitu, J. D. Protasiewicz, A. Kirschning, K. S. Feldman, T. Wirth, S. Quideau, S. Hara, N. Yoneda, L. Skulski, S. Spyroudis, V. V. Grushin, V. W. Pike, D. A. Widdowson, and many others. During the 1980s - 1990s, hypervalent iodine research had been summarized in several reviews and books. Most notable were the two books published in 1992 and 1997 by A. Varvoglis: a comprehensive monograph "The Organic Chemistry of Polycoordinated lodine" 18 and a book on the application of hypervalent iodine compounds in organic synthesis. ${ }^{19}$ Several general reviews and numerous book chapters and specialized reviews were also published during 1980s and 1990s.

Since the beginning of the 21st century, the chemistry of organohypervalent iodine compounds has experienced an explosive development. Five books ${ }^{1-5}$ and several hundred reviews summarizing various aspects of hypervalent iodine chemistry have been published since the year of 2000, and hundreds (if not thousands) of research works utilizing hypervalent iodine reagents are published every year. Since 2001, the International Conference on Hypervalent lodine Chemistry (ICHIC) has been convened on a regular basis. Previous ICHIC conferences were held in Kallithea, Greece (12-14 September 2001), Thessaloniki, Greece (1-2 June 2006), Bordeaux, France (4-7 July 2010), Chiba, Japan (2-5 July 2014), Les Diablerets, Switzerland (3-6 July 2016), and Cardiff, UK (1-4 July 2018). The 7th International Conference on Hypervalent lodine Chemistry (ICHIC-2021) will be held in Moscow State University, Russia, from $27^{\text {th }}$ June to $1^{\text {st }}$ July 2021 . ICHIC-2021 will be dedicated to the memory of Prof. Nikolay S. Zefirov (1935-2017) who made a significant contribution to the field of hypervalent iodine chemistry. Similar to previous ICHIC conferences, the scientific program of ICHIC2021 covers all key topics of hypervalent iodine chemistry including: (1) Synthesis, structure and bonding, (2) Applications in organic synthesis, (3) Mechanistic studies, (4) Coordination chemistry, (5) Applications in materials science, (6) Theoretical and spectroscopic studies.

\section{General classification of hypervalent iodine compounds}

Organoiodine(III) compounds are commonly classified by the type of ligands attached to the iodine atom. The following general classes of polyvalent iodine compounds have found broad application as reagents in organic synthesis: (difluoroiodo)arenes 1, (dichloroiodo)arenes 2, iodosylarenes 3, [bis(acyloxy)iodo]arenes 4, aryliodine(III) organosulfonates $\mathbf{5}$, iodonium salts $\mathbf{6}$, iodonium ylides $\mathbf{7}$, iodonium imides $\mathbf{8}$, and benziodoxole derivatives 9-11 (Figure 1). The most important and commercially available representatives of aryliodine(III) carboxylates 4 are represented by (diacetoxyiodo)benzene PhI(OAc) 2 , which is usually abbreviated as PIDA (phenyliodine diacetate), and by [bis(trifluoroacetoxy)iodo]benzene PhI(OCOCF$)_{2}$, abbreviated as PIFA 
[(phenyliodine bis(trifluoroacetate)]. The most important representative of aryliodine(III) organosulfonates 5, the commercially available [hydroxy(tosyloxy)iodo]benzene PhI(OH)OTs, is abbreviated as HTIB and is also known as Koser's reagent.

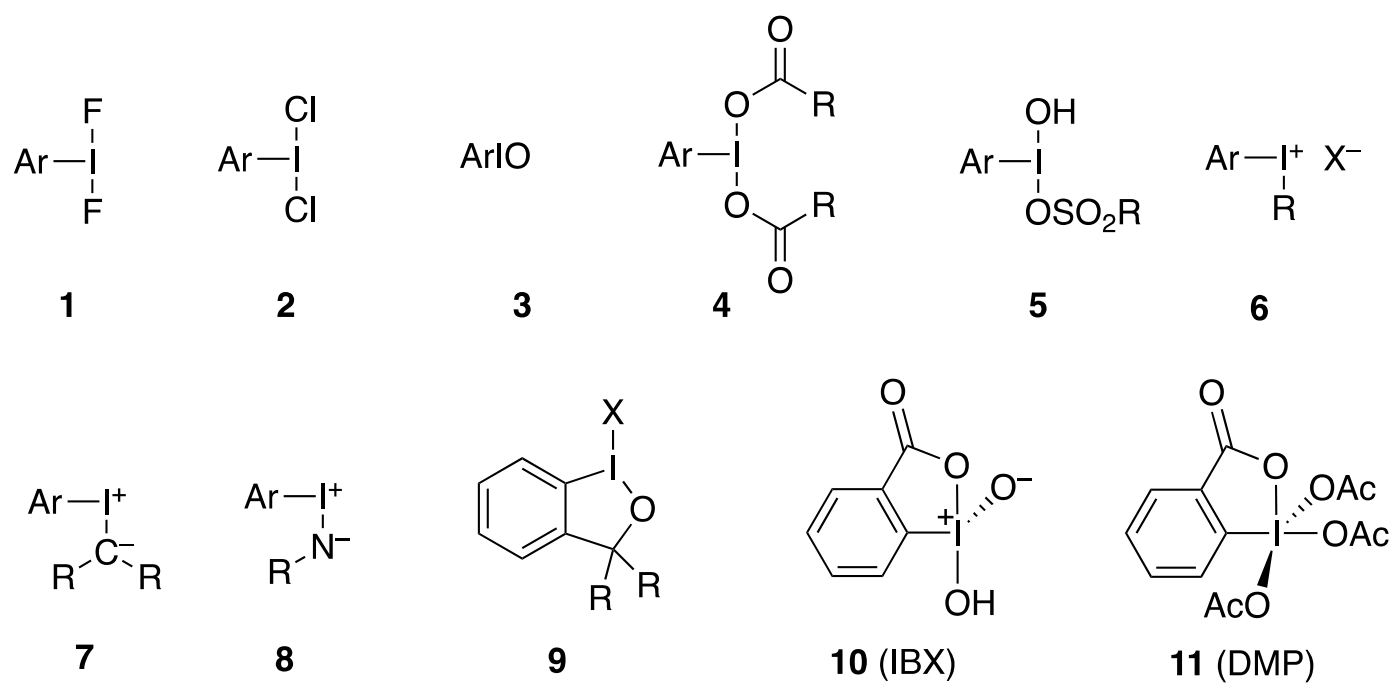

Figure 1. Common classes of hypervalent iodine compounds.

Polyvalent iodine compounds 1-11 have found wide application in organic synthesis as efficient reagents for various oxidative transformations. (Difluoroiodo)arenes $\mathbf{1}$ and (dichloroiodo)arenes $\mathbf{2}$ are effective fluorinating and chlorinating reagents, respectively. lodosylarenes 3, aryliodine(III) carboxylates 4 and organosulfonates $\mathbf{5}$ are strong oxidizing agents and have found widespread application as reagents for oxygenation and oxidative functionalization of organic substrates. lodonium salts 6 in general do not possess significant oxidizing properties, but have a diverse reactivity pattern mainly due to the exceptional leaving group ability of the iodoarene fragment. Iodonium ylides $\mathbf{7}$ and imides $\mathbf{8}$ are excellent carbene and nitrene precursors, respectively. Benziodoxoles $\mathbf{9}$ have a considerably higher stability compared to their acyclic analogs, which made possible the development of several valuable group transfer reagents. The most important organoiodine(V) compounds are represented by IBX (10) and DMP (11) which have found broad application as efficient oxidizing reagents.

\section{Recent developments and future perspectives}

Current surging interest in hypervalent iodine chemistry is driven mainly by the very useful oxidizing properties of iodine(III) and iodine(V) reagents, combined with their benign environmental character and commercial availability. The development of numerous new synthetic methodologies has been inspired by exploration and practical utilization of the similarities between hypervalent iodine and derivatives of heavy transition metals. In particular, hypervalent iodine reagents and catalysts can effectively promote coupling reactions leading to the formation of new $\mathrm{C}-\mathrm{C}, \mathrm{C}-\mathrm{N}$ and other carbon-element bonds. The utilization of hypervalent iodine reagents for the construction of carbon-carbon bonds was surveyed in two reviews. ${ }^{20,21}$ Numerous recent reviews have summarized reactions of hypervalent iodine reagents leading to the formation of new $\mathrm{C}-\mathrm{N}$ bonds. ${ }^{22-26}$ Fluorinations and other oxidative halogenations triggered by hypervalent iodine(III) 
compounds have been demonstrated to be synthetically useful reactions with excellent selectivities. ${ }^{27,28}$ The $^{2}$ use of iodine(III) species allowing facile formation of various heterocyclic system via oxidative formation of $\mathrm{C}$ $\mathrm{C}, \mathrm{C}-\mathrm{N}, \mathrm{C}-\mathrm{O}, \mathrm{C}-\mathrm{S}, \mathrm{N}-\mathrm{N}, \mathrm{N}-\mathrm{O}$, or $\mathrm{N}-\mathrm{S}$ bonds has recently been reviewed. ${ }^{29-34}$ Hypervalent iodine mediated oxidative methodologies have found wide application in total synthesis of natural products. ${ }^{35,36}$

The discovery of catalytic activity of iodine compounds in numerous oxidative transformations is one of the most impressive recent achievements. The development of highly efficient, enantioselective molecular catalysts based on the unique redox chemistry of iodine has added a new dimension to the field of hypervalent iodine chemistry and initiated a major surge of research activity. ${ }^{37-40}$

Numerous recent reviews have been dedicated to synthetic applications of several specific classes of hypervalent iodine compounds. Aryliodonium salts have attracted significant interest as electrophilic arylating reagents $^{41-47}$ and precursors for Positron Emission Tomography (PET). ${ }^{48,49}$ Iodonium ylides have also been recently utilized as PET precursors for nucleophilic radiofluorination. ${ }^{50,51}$

The development of the group-transfer benziodoxole-based reagents is one of the most significant recent achievements in the field of hypervalent iodine chemistry. ${ }^{52-55}$ Trifluoromethylbenziodoxoles have received the status of common trifluoromethylating reagents. ${ }^{52-57}$ Ethynylbenziodoxoles are useful alkynylating reagents. ${ }^{58-60}$ Azidobenziodoxoles are the most effective reagents for radical azidation. ${ }^{52-55,61,62}$ In general, radical and photochemical reactions of hypervalent iodine compounds belong now to one of the hottest areas of modern hypervalent iodine chemistry. ${ }^{63,64}$

Numerous new, useful hypervalent iodine reagents have recently been developed, such as: the most powerful iodine(V) oxidants, ${ }^{65}$ pseudocyclic hypervalent iodine reagents with improved physical properties and reactivity pattern, ${ }^{66,67}$ benzyne precursors that are triggered by water at room temperature, ${ }^{45}$ and watersoluble IBX derivatives. ${ }^{68}$

The development of new synthetic methodologies and the use of hypervalent iodine reagents in specific classes of reactions have attracted significant research activity. Examples of recent reviews dedicated to specific reactions include the following works: applications of hypervalent iodine(III) reagents in direct $\mathrm{C}-\mathrm{H}$ bond functionalization, ${ }^{69}$ iodosobenzene-mediated construction of heterocyclic scaffolds, ${ }^{70}$ functionalization of alkenes using hypervalent iodine reagents, ${ }^{71,72}$ hypervalent iodine-mediated synthesis of spiroheterocycles, ${ }^{73}$ organocatalytic approaches used to promote group transfer from hypervalent iodine species, ${ }^{74}$ phenol dearomatization reactions using hypervalent iodine reagents, ${ }^{75,76}$ rearrangements induced by hypervalent iodine, ${ }^{77}$ applications of hypervalent iodine(III) reagents in organophosphorus chemistry, ${ }^{78}$ hypervalent iodine reagents in transition metal chemistry, ${ }^{79}$ and many other works. Theoretical studies of the mechanisms of catalytic and stoichiometric iodine-mediated reactions has been discussed in numerous publications. ${ }^{80-87}$

New methods for generation of hypervalent iodine compounds using green chemistry approaches have recently been developed. In particular, the anodic oxidation of iodoarenes can serve as efficient method for the synthesis of hypervalent iodine reagents, eliminating the necessity to use hazardous chemical oxidants. The hypervalent iodine species generated at the anode can be utilized as either in-cell or ex-cell mediators for various valuable oxidative transformations such as fluorinations and oxidative cyclizations. ${ }^{88}$ The aerobic synthesis of iodine(III) and iodine(V) reagents represents another environmentally sustainable procedure. This method is based on chemical interception of reactive intermediates generated during aldehyde autooxidation accomplishing the oxidation of aryl iodides. The aerobically generated hypervalent iodine intermediates can be utilized in an array of oxidative functionalizations of organic substrates. ${ }^{89}$

The industrial applications of hypervalent iodine chemistry at present are limited mainly to the use of hypervalent iodine oxidants in kilogram-scale syntheses of various pharmaceuticals and utilization of 
diaryliodonium salts in polymer science and industry. ${ }^{2,4,8}$ In particular, iodonium salts have found broad industrial application as initiators of polymerization. ${ }^{9,90,91}$ It is expected that the interest in practical applications of hypervalent iodine compounds will significantly grow in the future.

\section{Conclusions}

In conclusion, this brief survey of recently published books and reviews demonstrates increasing research activity in different areas of hypervalent iodine chemistry. Hypervalent iodine reagents and synthetic methodologies involving hypervalent iodine species have become essential tools of modern organic synthesis. We anticipate that the inspiring chemistry of hypervalent iodine compounds will continue to attract significant interest and research activity in the future.

\section{Acknowledgements}

Our work on development of new hypervalent iodine reagents was supported by a research grant from the National Science Foundation (CHE-1759798).

\section{References}

1. Kaiho, T.; Ed. lodine Chemistry And Applications; John Wiley \& Sons, Inc.: Chichester (UK), 2015. https://doi.org/10.1002/9781118909911

2. Patai's Chemistry of Functional Groups: The Chemistry of Hypervalent Halogen Compounds; Olofsson, B.; Marek, I.; Rappoport, Z., Eds.; Wiley, 2019.

3. Hypervalent lodine Chemistry: Modern Developments in Organic Synthesis. Top. Curr. Chem. 373; Wirth, T., Ed.; Springer, 2016.

4. Zhdankin, V. V. Hypervalent lodine Chemistry: Preparation, Structure, and Synthetic Applications of Polyvalent lodine Compounds; Wiley: Chichester UK., 2013.

https://doi.org/10.1002/9781118341155

5. Wirth, T.; Ed. Hypervalent lodine Chemistry: Modern Developments in Organic Synthesis. [In: Top. Curr. Chem., 2003; 224], 2003.

https://doi.org/10.1007/3-540-46114-0

6. Yoshimura, A.; Zhdankin, V. V. Chem. Rev. 2016, 116, 3328-3435.

https://doi.org/10.1021/acs.chemrev.5b00547

7. Zhdankin, V. V.; Muñiz, K. J. Org. Chem. 2017, 82, 11667-11668.

https://doi.org/10.1021/acs.joc.7b02531

8. Yusubov, M. S.; Zhdankin, V. V. Resource-Efficient Technologies 2015, 1, 49-67. https://doi.org/10.1016/j.reffit.2015.06.001

9. Hypervalent lodine Compounds in Polymer Science and Technology; 1st Ed.; Vaish, A.; Tsarevsky, N. V., Eds.; John Wiley \& Sons, Inc., 2018.

10. Willgerodt, C. J. Prakt. Chem. 1886, 33, 154. https://doi.org/10.1002/prac.18860330117

11. Willgerodt, C. Ber. Dtsch. Chem. Ges. 1892, 25, 3498.

https://doi.org/10.1002/cber.18920250287

12. Willgerodt, C. Ber. 1892, 25, 3494. 
https://doi.org/10.1002/cber.189202502221

13. Hartman, C.; Mayer, V. Chem. Ber. 1893, 26, 1727-1732.

https://doi.org/10.1002/cber.189302602109

14. Hartmann, C.; Meyer, V. Ber. Dtsch. Chem. Ges. 1894, 27, 426.

https://doi.org/10.1002/cber.18940270183

15. Willgerodt, C. Die Organischen Verbindungen mit Mehrwertigen Jod; Ferdinand Enke Verlag: Stuttgart, 1914.

16. Sandin, R. B. Chem. Rev. 1943, 32, 249-276.

https://doi.org/10.1021/cr60103a001

17. Banks, D. F. Chem. Rev. 1966, 66, 243-266.

https://doi.org/10.1021/cr60241a001

18. Varvoglis, A. The Organic Chemistry of Polycoordinated lodine; VCH Publishers, Inc.: New York, 1992.

19. Varvoglis, A. Hypervalent lodine in Organic Synthesis; Academic Press: London, 1997.

20. Hyatt, I. F. D.; Dave, L.; David, N.; Kaur, K.; Medard, M.; Mowdawalla, C. Org. Biomol. Chem. 2019, 17, 7822-7848.

https://doi.org/10.1039/C90B01267B

21. Liu, J.; Xiong, X.; Chen, J.; Wang, Y.; Zhu, R.; Huang, J. Curr. Org. Synth. 2018, 15, 882-903.

https://doi.org/10.2174/1570179415666180720111422

22. Muniz, K. Acc. Chem. Res. 2018, 51, 1507-1519.

https://doi.org/10.1021/acs.accounts.8b00137

23. Reddy Kandimalla, S.; Prathima Parvathaneni, S.; Sabitha, G.; Subba Reddy, B. V. Eur. J. Org. Chem. 2019, 2019, 1687-1714.

https://doi.org/10.1002/ejoc.201801469

24. Maiti, S.; Alam, M. T.; Bal, A.; Mal, P. Adv. Synth. Catal. 2019, 361, 4401-4425.

https://doi.org/10.1002/adsc.201900441

25. Muniz, K. Top. Curr. Chem. 2016, 373, 105-134.

26. Yoshimura, A.; Yusubov, M. S.; Zhdankin, V. V. Arkivoc 2019, (i), 228-255.

https://doi.org/10.24820/ark.5550190.p010.975

27. Arnold, A. M.; Ulmer, A.; Gulder, T. Chem. - Eur. J. 2016, 22, 8728-8739.

https://doi.org/10.1002/chem.201600449

28. Kohlhepp, S. V.; Gulder, T. Chem. Soc. Rev. 2016, 45, 6270-6288.

https://doi.org/10.1039/C6CS00361C

29. Samanta, R.; Matcha, K.; Antonchick, A. P. Eur. J. Org. Chem. 2013, 5769-5804.

https://doi.org/10.1002/ejoc.201300286

30. Murarka, S.; Antonchick, A. P. Top. Curr. Chem. 2016, 373, 75-104.

https://doi.org/10.1007/128 2015647

31. Zheng, Z. S.; Zhang-Negrerie, D.; Du, Y. F.; Zhao, K. Sci. China: Chem. 2014, 57, 189-214. https://doi.org/10.1007/s11426-013-5043-1

32. Budhwan, R.; Yadav, S.; Murarka, S. Org. Biomol. Chem. 2019, 17, 6326-6341.

https://doi.org/10.1039/C90B00694J

33. Fujita, M. Heterocycles 2018, 96, 563-594.

https://doi.org/10.3987/REV-17-877

34. Yoshimura, A.; Zhdankin, V. V. Arkivoc 2017, (i), 99-116.

https://doi.org/10.24820/ark.5550190.p010.013 
35. Maertens, G.; L'Homme, C.; Canesi, S. Front. Chem. 2014, 2, 1-16.

https://doi.org/10.3389/fchem.2014.00115

36. Dohi, T.; Kita, Y. Top. Curr. Chem. 2016, 373, 1-24.

37. Parra, A. Chem. Rev. 2019, 119, 12033-12088.

https://doi.org/10.1021/acs.chemrev.9b00338

38. Flores, A.; Cots, E.; Bergès, J.; Muñiz, K. Adv. Synth. Catal. 2019, 361, 2-25.

https://doi.org/10.1002/adsc.201800521

39. Ghosh, S.; Pradhan, S.; Chatterjee, I. Beilstein J. Org. Chem. 2018, 14, 1244-1262.

https://doi.org/10.3762/bjoc.14.107

40. Kumar, R.; Wirth, T. Top. Curr. Chem. 2016, 373, 243-262.

41. Aradi, K.; Toth, B. L.; Tolnai, G. L.; Novak, Z. Synlett 2016, 27, 1456-1485.

https://doi.org/10.1055/s-0035-1561369

42. Kumar, D.; Arun, V.; Pilania, M.; Mehra, M. K.; Khandagale, S. B. Chem. Biol. Interface 2016, 6, $270-281$.

43. Wang, M.; Chen, S.; Jiang, X. Chem. - Asian J. 2018, 13, 2195-2207.

https://doi.org/10.1002/asia.201800609

44. Olofsson, B. Top. Curr. Chem. 2016, 373, 135-166.

45. Yoshimura, A.; Saito, A.; Zhdankin, V. V. Chem. - Eur. J. 2018, 24, 15156-15166.

https://doi.org/10.1002/chem.201802111

46. Chatterjee, N.; Goswami, A. Eur. J. Org. Chem. 2017, 2017, 3023-3032.

https://doi.org/10.1002/ejoc.201601651

47. Hartrampf, F.; Toombs-Ruane, H. Aust. J. Chem. 2015, 68, 699-702.

https://doi.org/10.1071/CH14658

48. Preshlock, S.; Tredwell, M.; Gouverneur, V. Chem. Rev. 2016, 116, 719-766.

https://doi.org/10.1021/acs.chemrev.5b00493

49. Yusubov, M. S.; Svitich, D. Y.; Larkina, M. S.; Zhdankin, V. V. Arkivoc 2013, (i), 364-395.

50. Bernard-Gauthier, V.; Lepage, M. L.; Waengler, B.; Bailey, J. J.; Liang, S. H.; Perrin, D. M.; Vasdev, N.;

Schirrmacher, R. J. Nucl. Med. 2018, 59, 568-572.

https://doi.org/10.2967/jnumed.117.197095

51. Yusubov, M. S.; Yoshimura, A.; Zhdankin, V. V. Arkivoc 2016, (i), 342-374.

https://doi.org/10.3998/ark.5550190.p009.732

52. Boelke, A.; Finkbeiner, P.; Nachtsheim, B. J. Beilstein J. Org. Chem. 2018, 14, 1263-1280.

https://doi.org/10.3762/bjoc.14.108

53. Hari, D. P.; Caramenti, P.; Waser, J. Acc. Chem. Res. 2018, 51, 3212-3225.

https://doi.org/10.1021/acs.accounts.8b00468

54. Li, Y.; Hari, D. P.; Vita, M. V.; Waser, J. Angew. Chem., Int. Ed. 2016, 55, 4436-4454.

https://doi.org/10.1002/anie.201509073

55. Zhdankin, V. V. Adv. Heterocycl. Chem. 2015, 115, 1-91.

https://doi.org/10.1016/bs.aihch.2015.03.003

56. Fruh, N.; Charpentier, J.; Togni, A. Top. Curr. Chem. 2016, 373, 167-186.

https://doi.org/10.1007/128 2015658

57. Charpentier, J.; Fruh, N.; Togni, A. Chem. Rev. 2015, 115, 650-682.

https://doi.org/10.1021/cr500223h

58. Waser, J. Synlett 2016, 27, 2761-2773.

https://doi.org/10.1055/s-0036-1589409 
59. Waser, J. Top. Curr. Chem. 2016, 373, 187-222.

https://doi.org/10.1007/128 2015660

60. Kaschel, J.; Werz, D. B. Angew. Chem., Int. Ed. 2015, 54, 8876-8878.

https://doi.org/10.1002/anie.201503405

61. Vita, M. V.; Waser, J. Angew. Chem. Int. Ed. 2015, 54, 5290-5292.

https://doi.org/10.1002/anie.201501666

62. Olding, A.; Ho, C. C. Aust. J. Chem. 2019, 72, 646-648.

https://doi.org/10.1071/CH19247

63. Wang, X.; Studer, A. Acc. Chem. Res. 2017, 50, 1712-1724.

https://doi.org/10.1021/acs.accounts.7b00148

64. Wang, L.; Liu, J. Eur. J. Org. Chem. 2016, 2016, 1813-1824.

https://doi.org/10.1002/ejoc.201501490

65. Yusubov, M. S.; Postnikov, P.; Yoshimura, A.; Zhdankin, V. V. Synlett 2019, Ahead of Print; DOI:

10.1055/s-0039-1690761

https://doi.org/10.1055/s-0039-1690761

66. Yoshimura, A.; Yusubov, M. S.; Zhdankin, V. V. Org. Biomol. Chem. 2016, 14, 4771-4781. ttps://doi.org/10.1039/C60B00773B

67. Zhdankin, V. V.; Protasiewicz, J. D. Coord. Chem. Rev. 2014, 275, 54-62.

https://doi.org/10.1016/j.ccr.2014.04.007

68. Han, Y.-C.; Zhang, C. Tetrahedron Lett. 2018, 59, 3052-3064.

https://doi.org/10.1016/j.tetlet.2018.06.059

69. Narayan, R.; Manna, S.; Antonchick, A. P. Synlett 2015, 26, 1785-1803.

https://doi.org/10.1055/s-0034-1379912

70. Gayen, K. S.; Chatterjee, N.; Khamarui, S.; Tarafdar, P. K. Eur. J. Org. Chem. 2018, 2018, 425-439. https://doi.org/10.1002/ejoc.201701306

71. Lee, J. H.; Choi, S.; Hong, K. B. Molecules 2019, 24, 2634.

https://doi.org/10.3390/molecules24142634

72. Li, X.; Chen, P.; Liu, G. Beilstein J. Org. Chem. 2018, 14, 1813-1825.

https://doi.org/10.3762/bjoc.14.154

73. Xing, L.; Zhang, Y.; Du, Y. Curr. Org. Chem. 2019, 23, 14-37. https://doi.org/10.2174/1385272822666181211122802

74. Ghosh, M. K.; Rajkiewicz, A. A.; Kalek, M. Synthesis 2019, 51, 359-370. https://doi.org/10.1055/s-0037-1609639

75. Singh, F. V.; Kole, P. B.; Mangaonkar, S. R.; Shetgaonkar, S. E. Beilstein J. Org. Chem. 2018, 14, $1778-1805$. https://doi.org/10.3762/bjoc.14.152

76. Quideau, S.; Pouysegu, L.; Peixoto, P. A.; Deffieux, D. Top. Curr. Chem. 2016, 373, 25-74.

https://doi.org/10.1007/128 2015665

77. Maertens, G.; Canesi, S. Top. Curr. Chem. 2016, 373, 223-241.

https://doi.org/10.1007/128 2015657

78. Murphy, G. K.; Racicot, L.; Carle, M. S. Asian J. Org. Chem. 2018, 7, 837-851.

https://doi.org/10.1002/ajoc.201800058

79. Sousa e. Silva, F. C.; Tierno, A. F.; Wengryniuk, S. E. Molecules 2017, 22, 780.

https://doi.org/10.3390/molecules22050780

80. Luthi, H. P.; Togni, A. Chimia 2014, 68, 624-628. 
https://doi.org/10.2533/chimia.2014.624

81. Pinto de Magalhaes, H.; Luthi, H. P.; Togni, A. J. Org. Chem. 2014, 79, 8374-8382.

https://doi.org/10.1021/jo501714f

82. Pinto de Magalhaes, H.; Luthi, H. P.; Bultinck, P. Phys. Chem. Chem. Phys. 2016, 18, 846-856.

https://doi.org/10.1039/C5CP05343A

83. Koichi, S.; Leuthold, B.; Luthi, H. P. Phys. Chem. Chem. Phys. 2017, 19, 32179-32183.

https://doi.org/10.1039/C7CP05943D

84. Pinto de Magalhaes, H.; Togni, A.; Luthi, H. P. J. Org. Chem. 2017, 82, 11799-11805.

https://doi.org/10.1021/acs.joc.7b01716

85. Breugst, M.; von der Heiden, D. Chem. - Eur. J. 2018, 24, 9187-9199.

https://doi.org/10.1002/chem.201706136

86. Ivanov, A. S.; Popov, I. A.; Boldyrev, A. I.; Zhdankin, V. V. Angew. Chem., Int. Ed. 2014, 53, 9617-9621. https://doi.org/10.1002/anie.201405142

87. Yusubov, M. S.; Soldatova, N. S.; Postnikov, P. S.; Valiev, R. R.; Svitich, D. Y.; Yusubova, R. Y.; Yoshimura, A.; Wirth, T.; Zhdankin, V. V. Eur. J. Org. Chem. 2018, 2018, 640-647.

https://doi.org/10.1002/ejoc.201701595

88. Elsherbini, M.; Wirth, T. Chem. - Eur. J. 2018, 24, 13399-13407.

https://doi.org/10.1002/chem.201801232

89. Maity, A.; Powers, D. C. Synlett 2019, 30, 257-262.

ttps://doi.org/10.1055/s-0037-1610338

90. Asandei, A. D. Chem. Rev. 2016, 116, 2244-2274.

https://doi.org/10.1021/acs.chemrev.5b00539

91. Yusubov, M. S.; Yoshimura, A.; Zhdankin, V. V. New Materials, Compounds and Applications 2019, 3, 514.

\section{Author's Biography}

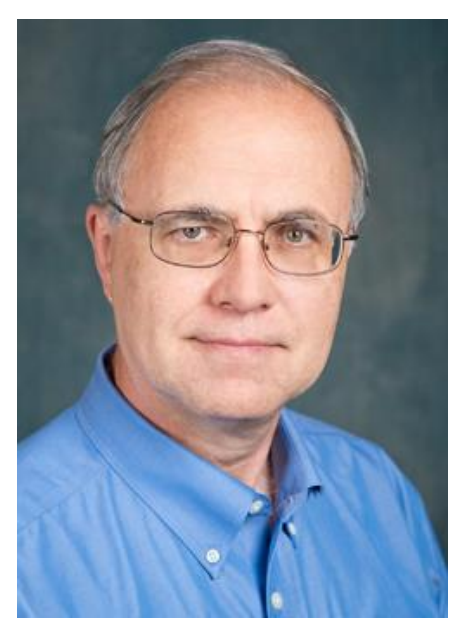

Viktor V. Zhdankin was born in Ekaterinburg, Russian Federation. His M.S. (1978), Ph.D. (1981), and Doctor of Chemical Sciences (1986) degrees were earned at Moscow State University. He moved to the University of Utah in 1990, where he worked for three years as Instructor of organic chemistry and Senior Research Associate with Professor Peter J. Stang. In 1993, he joined the faculty of the University of Minnesota Duluth, 
where he is currently a Professor of Chemistry. Dr. Zhdankin has published about 300 research papers, gave over a hundred research presentations in many countries, edited several books, co-authored the Handbook of Heterocyclic Chemistry (3rd Edition, 2010) with Professors A. R. Katritzky, C. A. Ramsden, and J. A. Joule, and authored a book on Hypervalent lodine Chemistry (Wiley, 2013). He has also published a general introductory textbook on Organic Chemistry (Cognella, 2018, https://titles.cognella.com/organic-chemistry9781634878999). His main research interests are in the areas of synthetic and mechanistic organic chemistry of hypervalent main-group elements and organofluorine chemistry. In 2011 he received the National Award of the American Chemical Society for Creative Research \& Applications of lodine Chemistry. Since 2003 he is Scientific Editor and a Member of Control Board of Arkivoc. 